\title{
Conflict and Revolution in the Horn of Africa: Somali Republic in Focus
}

\author{
Nuru Ahmed Mohammed ${ }^{1}$ \\ Lecturer, Department of Political Science and International Relations, Woldia University
}

\begin{abstract}
This paper is typically focused on the issue of conflict and revolution in Somali. As an introduction it tries to explore the historical trajectories in Africa in general and Somali in particular. The paper narrates the development of Somali conflict since the early 1990s. The central emphasis is that what causes attract Somali in to these long ranged civil war and chaos. The paper argued that competition for power and resources, the colonial legacy and state repression were the long-term causes of the Somali conflict. It also deals with the adversarial relationship in the country which are the leading actors in the conflict; the roles that regional and international organizations as well as isolated sovereign states to mitigate the problem; interests of third parties in the conflict like USA, Ethiopia, Kenya, Eritrea and so on. Finally, the paper tried to present the probable future of Somalia from scholar's point of view and expectations from Somali.
\end{abstract}

Keywords: Somalia, Conflict, Revolution, Civil War

DOI: $10.7176 / \mathrm{IAGS} / 87-02$

Publication date:October $31^{\text {st }} 2020$

\subsection{INTRODUCTION}

The planet earth has seven continents. Among them, Africa is the second in its size and includes nearly 56 states, with the newly emerged tiny states the number will vary. The continent is the cradle/ source of human beings. But, especially, since their independence conflict and war was prominent and also becoming the main characteristics of the area.

Eastern African countries in their policies aimed at achieving peace, prosperity and cooperation with other states. But these objectives had been challenged by violent conflicts and civil wars in a region that has been steeped in warfare for decades. The current conflicts in the Horn of Africa include civil war in Darfur, protracted state collapse in Somalia, deep hostility and a stalled peace process between Ethiopia and Eritrea, a fragile peace agreement between North and South Sudan, a border dispute between Eritrea and Djibouti and periodic bouts of unrest in the Ogaden and Northern Uganda (Sally Healy, 2009:1).

Unlike many African populations, the overwhelming majority of the Somalis are part of a single, homogeneous ethnic group. All Somalis are Muslim and share the same language and culture. Nevertheless, one of the most terrible civil wars in Africa has been waged in this country for more than two decades. Somalia has been without a functioning central government since the late dictator General Mohamed Siad Barre was ousted in 1991(Afyare Elmi and Dr Abdullahi Barise, n.d: 32).

This paper assesses conflict and revolution in Somalia. It will keep in touch issues like causes for the conflict, contesting parties with their perception, behaviors and goals, their capacity as well as the role of other involving actors. It also will provide a brief account about Somalia before state of war.

\subsection{HISTORICAL BACKGROUND}

In many African states, ethnicity has been considered as a major obstacle to modem state-building causing political instability and violent conflict. In Somalia, political observers and analysts were more optimistic. They assumed Somalis share the same ethnicity, one religion, a common language and a predominantly pastoral culture: a predisposition for the development of modem nationalism. The egalitarian character of Somali society promised a political role model for other African states. But yet, Somalia was overtaken by a bloody civil war after the overthrow of Siyaad Barre's dictatorial regime in 1991 (Christian Webersik, 2004: 16).

After independence, between 1960 and 1969, Somali was ruled by two democratically elected civilian governments (As Ahmed I. Samanter, 1988 cited in CDR, 2004: 11). But due to the exploitation of clan identities by the political system, the election between 1964 and 1967 were backed up with electoral frauds, angry demonstration, government-public clashes, inter clan violence and the creation of clan based political parties(CDR, 2004: 11).

Many of the conflicts in the Horn challenged the basis of statehood. This is true for the dynamics in Somalia (Sally Healy, 2009: 5).

On 15 October 1969, the second president of Somalia, Mr. Abdirshid Ali Sharms'arke, was assassinated by one of his guard (CDR, 2004: 12). This year was a decisive development that pushes one foot for the military

\footnotetext{
1. The author can be reached at: nurafato@gmail.com, Tell: 0912031373
} 
assistance of Soviet Union which was the overthrown of the civilian government and the coming of Siyaad Barre to power with scientific socialism (Schwab, 1978: 12).

From 1969 to 1990, president and military dictator Siyaad Barre oversaw a campaign of widespread atrocities that decimated Somali civil society. To quash separatist movements in the 1980s, the Somali Armed Forces targeted civilians in the northwest, culminating in the bloody 1988 siege of the regional capital Hargeisa, which claimed 5,000 civilian lives (Sally Healy and Mark Bradbury, 2014).

After the Soviet Union withdrew from Somalia during the Ogaden war, the US did not show much interest in the stability of the country. In the absence of a hegemonic power and with massive weaponry provided by former patrons, Somalia experienced civil strife and banditry on a massive scale in 1991 and 1992(Christian Webersik, 2004:519). In these year clan war and famine becomes prominent in Somalia (Sally Healy and Mark Bradbury, 2014: 10).

\subsection{SOMALIA at WAR}

In the late 1980s and 1990s, the political conflict in Somalia degenerated into a governmental crisis which eventually led to a general militarized social conflict throughout the clan faction network. The institutionalized principles of clan equality and representation in politics constituted a conceptual framework and basis for power sharing and government crisis management but failed to resolve the intense socio-political conflicts of the decade (Florence Ssereo, 2003:3).

In other words, Somalia since the early 1990s debacles into three distinct crises - collapse of central government, protracted armed conflict, and lawlessness. This in turn resulted in significant changes in the nature and intensity of conflict and lawlessness (Ken Menkhaus, 203:405).

The pre-civil war state has been broken into pieces. Somaliland had declared independence in 1991, campaigns for recognition as a state and has not been involved in the conflict in south-central regions. Puntland's assumption of autonomy in 1998 and the emergence of several mini-states in south central Somalia, with varying degrees of allegiance to the internationally recognized federal government, have further distorted the geographical and administrative limits of the term 'Somalia' (LPI, 2014:8).

Somalia's civil war began long before the state collapse. The 1977-78 Ogaden war left the regime not only deeply unpopular, militarily humbled, economically insolvent but also internationally isolated. After continuous struggle, in January 1991 USC forces seized the capital as the SNM took control in the North West. Latter on Jan. 26, 1991, Siyad Barre was flight from Mogadishu (CDR, 2004: 13-14). But Somalia was joined an ever ending journey of political turmoil or civil war.

Since the ousting of Siyaad Barre in January 1991, Somalia has not experienced political stability and widespread economic prosperity. Clan loyalties persisted and, in the years that followed, clan affiliation became an important protection for individuals against violence (Christian Webersik, 2004:516 and Sally Healy, 2009:8).

The conflict could have been adequately characterized as a civil war among Somali clans with occasional intervention from regional powers (such as Ethiopia's operations against the Islamist militia of Al-Ittehad in 199496 and 1999). The clan-oriented civil war narrative changed dramatically with the onset of the 'war on terrorism' after the 11 September 2001 attacks on US. The domestic dimension of the conflict has since been overshadowed by a focus on 'Islamist' militias (Ken Menkhaus, 203:411-12; Bjorn Moller, 2009:14 and LPI, 2014:8).

In June 2006, an alliance of 17 Islamist groups under the umbrella of Islamic Courts Union came to power in Mogadishu and other parts of south-central Somalia. Within six months, however, it was dislodged by Ethiopian forces, backed by the United States and other Western powers. An African Union military mission - AMISOM has been operational since 2007. So, 'civil war' has become an obsolete epithet, no longer adequate to describe the Somali conflict (LPI, 2014:8).

The Islamic Courts Union has since been dispersed and fragmented; with the Islamist youth group al-Shabab becoming the central actor in warfare. The prevalent media and political discourse tends to divide Somali groups into pro- and anti-al-Shabab entities, even though the conflict remains much more complex and parties to it much more diverse than this binary division suggests (Ibid).

Somalia has made international news for over two decades, with the headlines focusing on Somalia being in a state of civil war characterized by clan warfare and humanitarian catastrophe, then as a failed state, and now as a potential safe haven for organized gangs, pirates and terrorists (Ken Menkhaus, n.d: 35-37 and LPI, 2014 :13).

A cholera outbreak due to unsanitary water kills hundreds of Somalis in 2000. And between 2001 and 2002 the United Nations declares that it will be pulling its international staff and aid workers from Somalia because of the dangerous fighting conditions and attempts at kidnapping. The U.S. government also suspects that Al-Qaeda fighters may be seeking refuge in Somalia, and announces increased military operations in region (AMG, 2015: $1)$.

Between 2002 and 2005, dozens of Somalis were abducted and assassinated in a dirty war between 'terrorists' and 'counter-terrorists' (LPI, 2014:13). In 2003 an interim government is inaugurated in Kenya, in hopes of putting together a central government. This is the 14th attempt since the 1991 coup. Col. Abdullahi Yusuf is elected interim 
president by the new governing body. The government functions in exile in neighboring Kenya (Ken Menkhaus, n.d:38 and AMG, 2015: 1).

Up to 2005, there was heterogeneity and different forms of political Islam in Somalia. Within groups such as Al Itihad Al Islami (AIAI), an Islamist movement founded in 1984 and militarily active in Somalia throughout the 1990s, and the Islamic Courts Union (ICU), established in 2006 influential leaders have varied claims (LPI, 2014:13).

Despite their aim to transcend 'clan' and establish an Islamic state, All Islamist groups had to cooperate with clan and sub-clan elders and warlords and their militias. Until 2005, militant Islamists did not enjoy popular support in Somalia. They were also not well connected internationally (Ibid).

The groups condition was changed with the military invasion by Ethiopia and the establishment of the Transitional Federal Government (TFG) under Abdullahi Yusuf in late 2004, who gained international recognition while lacking legitimacy in most parts of Somalia (Ken Menkhaus, n.d:38). Particularly, the joint Ethiopian and US counterterrorism strategy after the 9/11 attacks contributed to the radicalization of a small group of dedicated jihadists, which provided the nucleus for the emergence of more radical outfits in Somalia ( Napoleon, 2010 and LPI, 2014:13).

In early 2006 Ethiopia and the US encouraged and paid a group of warlords to form the Alliance for Restoration of Peace and Counterterrorism (ARPCT) in order to snatch terror suspects in Mogadishu and keep the local Shari'a courts in check. The local Islamic courts, joined forces to form the Islamic Courts Union (ICU) and attacked the warlord alliance. In June 2006 the local Islamic Courts managed to drive the warlords out of the capital. But it didn't continued for long (Bjorn Moller, 2009:15-16 and LPI, 2014:13).

The international community, worried about the little known Somali 'Taliban' called for negotiations between the Islamists and the TFG, which was politically divided and spatially confined to the town of Baidoa in central Somalia. The negotiations were facilitated by the Arab League. The talks foundered in the autumn of 2006 and the ICU gained dominance (LPI, 2014:13). In the same year, the transitional government meets for the first time since 2004 in the town of Baidoa. Deadly fighting breaks out in Mogadishu between warring militias, killing and wounding hundreds of civilians. A militia-backed rival government to the Transitional Federal Government, called the Islamic Courts Union, seizes control of most of southern Somalia and captures Mogadishu from the U.S.-backed warlords (AMG, 2015: 1).

Besides ICU, Al-Shabaab has posed a threat to the sovereignty of Somalia for almost a decade. The group, whose name translates as 'The Youth', emerged as a small organizational cell in 2003, when a rift within Al-lttihad al-Islami (AIAI), a Salafi organization operating in Somalia since the 1990s, aligned its organization with the Islamic Courts Union. Since then, al-Shabaab has grown into a well-organized armed group, formally pledging allegiance to al-Qaeda in February 2012. The group professes a quasi-Salafist ideology with a notable Wahhabist inflection (Diego Cordano, 2015:2).

Since that time, militant Islamism has gained momentum in Somalia. Between January 2007 and December 2008, the Ethiopian and TFG forces were confronted by an Islamist and clan insurgency against what many in Mogadishu and southern Somalia perceived as foreign and Darood occupation. Abdullahi Yusuf belonged to the Darood clan family; after his election as president of Somalia, many clan-relatives joined him as soldiers in the Somali 'national' army. Mogadishu, on the other hand, is dominated by members of the Hawiye clan family that had been involved in brutal fighting with the Darood in the early 1990s. Thousands of civilians were killed in the war. ( Harun Hassan and Cedric Barnes, 2007 as cited in LPI , 2014:14)

Due to the 2006 Ethiopian invasion, the ICU leaders were exile to Eritrea. One side of the group was lead by the former ICU-Chairman, Sheikh Sharif Sheikh Ahmed and Sheikh Hasan Dahir Aweys heads a group who refused to join the dialogue with the government (LPI, 2014:14).

The Ethiopian army left Somalia in January 2009, under the terms of the UN sponsored Djibouti peace agreement, signed in August 2008 between the TFG and Somali armed opposition groups. Sheikh Sharif was finally made president of a new TFG established in Djibouti in January 2009(Amnesty International, 2011:6). Consequently, al-Shabab quickly filled the vacated positions (Bjorn Moller, 2009:18 and LPI, 2014:14). When Sheikh Sharif returned as president to Mogadishu in February 2009, his government was confined to a few neighbor-hoods in the capital and from May 2009 onward faced concerted attacks by al- Shabab led by Ahmed Abdi Godane aka Abu Zubeir, and the newly established Hizbul Islam under Sheikh Hasan Dahir Aweys(LPI, 2014:14).

It can be argued that the TFG survived only thanks to the protection of AMISOM, which was created by the African Union's Peace and Security Council in 2007, and financial backing from several donors. Hizbul Islam and al- Shabab merged in December 2010 after a period of rivalry for control of strategic positions in south-central Somalia, particularly Kismayo. By then al-Shabab had become the de facto government in most parts of southcentral Somalia and had established quite effective governance based on its version of Shari'a (LPI, 2014:14).

Al-Shabab was wrongfooted by a series of government and African peacekeeper offensives and a Kenyan army incursion in 2011. They withdrew from Mogadishu in August 2011, the port of Baidoa in February, the key 
town of Afgoye in May and the port of Merca in August, and lost their last urban stronghold - the major southern port of Kismayo - in October 2012, along with the major inland town of Wanla Weyn (BBC, May 5, 2015).

The Federal Government of Somalia (FGS) is the first elected permanent government in over two decades. The parliament elected Mohamed Osman Jawari as speaker and Hassan Sheikh Mohamud as the new president of Somalia on 10 September 2012. In December 2013, the president replaced the government of Abdi Farah Shirdon and appointed Abdiweli Sheikh Ahmed as the new Prime Minister (Diego Cordano, 2015:3).

Till today, no one is able to eliminate Al-shaba from Somalia. Even its threat had been increasing via indirect attacks, like bombing.

\subsection{PROMINENT ACTORS}

Since 2003, Al-Shabaab has become the central actor, which posed a threat to the sovereignty of Somalia for almost a decade. Its main goals are to liberate Somalia from "foreign colonizers" and to establish an administration axiomatic of Sharia law. Al-Shabab has a centralized structure led by an Amir and 'Elders Council' (Golaha Shuurada), but allows local governors (wali) to maintain a high degree of decision-making autonomy concerning everyday administration of their corresponding territories (Diego Cordano, 2015:2).

Life and peace institute identified various actors which actively take part in Somalia conflict since 1990s'. These key actors are the following (I have put them precisely in table):

\begin{tabular}{|c|c|c|}
\hline Actors & Objectives & Strategies \\
\hline $\begin{array}{l}\text { Somali Federal } \\
\text { Government (SFG) }\end{array}$ & $\begin{array}{l}\text { - security } \\
\text { - unemployment reduction } \\
\text { - national reconciliation } \\
\text { - reconstruction } \\
\text { - establishing effective judicial system }\end{array}$ & $\begin{array}{l}\text { - building the capacity of government } \\
\text { - improving the communication with } \\
\text { the public which in turn enhances the } \\
\text { effectiveness and standing of the } \\
\text { government }\end{array}$ \\
\hline $\begin{array}{l}\text { Harakat al-Shabab al- } \\
\text { Mujahideen (al-Shabab) }\end{array}$ & $\begin{array}{l}\text { - liberating Somalia from foreign } \\
\text { colonizers } \\
\text { - To unite Somalia } \\
\text { - To establish a just administration } \\
\text { based on Shari'a }\end{array}$ & $\begin{array}{l}\text { - armed jihad (fighting the occupying } \\
\text { forces) }\end{array}$ \\
\hline $\begin{array}{l}\text { Ahlu Sunna Wal Jama'a } \\
\text { (ASWJ) }\end{array}$ & $\begin{array}{l}\text { - driving out the Khawarijis from the } \\
\text { areas they administer } \\
\text { - to start he reconciliation process } \\
\text { among the people } \\
\text { - to form an all inclusive popularly } \\
\text { elected administration }\end{array}$ & $\begin{array}{l}\text { - self-reliance } \\
\text { - local and regional cooperation } \\
\text { - delivery of police, judicial and other } \\
\text { services }\end{array}$ \\
\hline $\begin{array}{l}\text { Puntland (existing regional } \\
\text { administration) }\end{array}$ & $\begin{array}{l}\text { - protecting the new constitution } \\
\text { - preserving law and order } \\
\text { - tighten the security }\end{array}$ & $\begin{array}{l}\text { - upgrading the armed forces in the } \\
\text { region } \\
\text { - transferring clan in to multi-party } \\
\text { system } \\
\text { - supporting the federal government }\end{array}$ \\
\hline $\begin{array}{l}\text { Galmudug } \quad \text { (existing } \\
\text { regional administration) }\end{array}$ & $\begin{array}{l}\text { - establishing Galmudug as stable } \\
\text { regional administration } \\
\text { - to bring together these different } \\
\text { groups (Himan, Heeb \& ASWJ) } \\
\text { - minimizing conflict in the region }\end{array}$ & $\begin{array}{l}\text { - the active involvement of the } \\
\text { Diaspora } \\
\text { - local and bottom-up reconciliation } \\
\text { - strengthening the federal government } \\
\text { developmental activities }\end{array}$ \\
\hline $\begin{array}{l}\text { Jubaland (emerging } \\
\text { regional administration) }\end{array}$ & $\begin{array}{l}\text { - building a viable regional } \\
\text { administration in Juba beginning with } \\
\text { Kismayo. } \\
\text { - removing Al-shabab with the support } \\
\text { of AMISOM }\end{array}$ & $\begin{array}{l}\text { - reconciliation laden by traditional } \\
\text { authorities }\end{array}$ \\
\hline Al-Islah & $\begin{array}{l}\text { - reviving Islamic education } \\
\text { - fostering values such as } \\
\text { modernization, national solidarity and } \\
\text { diminishing extremism } \\
\text { - spreading the mission of enlightened } \\
\text { Islam }\end{array}$ & $\begin{array}{l}\text {-Using "Islam" as a foundation of } \\
\text { education } \\
\text {-Arranging programmes and } \\
\text { disseminating messages in mosques, } \\
\text { schools, universities and the media } \\
\text {-Performing humanitarian and civic } \\
\text { activities through its NGO network }\end{array}$ \\
\hline
\end{tabular}

Source: (LPI, 2004:15-30)

Another actor actively involved in the conflict is the United States, which in recent years has pursued a twopronged policy, both providing funding, training, and logistical support to forces fighting al-Shabaab and 
escalating counterterrorism operations including Special Forces and drone attacks ( Diego Cordano, 2015:3).

Ethiopia is also an actor in Somali conflict. These is evident that she has been involving there with the name of protecting national and regional security. Ethiopia is blamed for sabotaging the TNG in 2000-02 and invasion in 2006 (Ken Menkhaus, n.d:39)

\subsection{CAUSES OF THE CONFLICT}

Somalia has a long history of armed conflict over land and livestock dating back to pre-colonial times but today, the influx of small arms into Somalia is leading to increased numbers of casualties. Also, weapons are traded within the country (Christian Webersik, 2004:519).

The current Somalia conflict can be traced back to colonization (Mohammed, 2009:7), when Great Britain, Italy, France and Ethiopia divided the Somali inherited territories of the horn in to five political jurisdictions including Northern Frontier District of Kenya (CRD, 2004:11 ). It also attributes to Cold War international relations, and the Barre dictatorship (Sally Healy and Mark Bradbury, 2014).

Joseph also holds that Somali had been a victim of the voice of colonization since one people and speaking the same language became scrambled in to [four] (Joseph Kimani, 1993: 3).

Social boundaries, with arbitrary external markers, have long existed among the southern Somali clans such as the Digil- Mirifle (Rahanweyn), among minority clans such as the Jareer and among nomadic clan families from the central and northern regions. The Rahanweyn community, which traditionally is engaged in rainfed agriculture and in agro-pastoralism, had been neglected by the Mogadishu regime for the past few decades, which in turn become a source of mismatch among the government and the public (Christian Webersik, 2004:517).

However, the immediate cause of the conflict is attached with the crisis of government in the post colonial period. Nepotism, corruption and clan competition were rapidly eroding the Somali's infant democratic system. Latter on the military dictatorship nature of Said Barre's government with unequal ethnic treatment exacerbates the conflict (CRD, 200: 11).

\subsection{EXTERNAL SUPPORT AND INVOLVEMENT}

The role of regional and international powers and the impact of their policies on the fragmented and broken countries, like Somalia, have a prominent importance (LPI, 2004:43). External actors like neighboring states, international organizations, non-regional foreign powers and non state actors play a significant role in Somalia to the contestant parties there (Bjorn Moller, 2009:1-29).

The FGS is supported by the African Union Mission in Somalia (AMISOM), a regional peacekeeping mission led by the African Union with the approval of the United Nations since 2007. The mission, legislated by UN Resolution 2182 (2014), has a military component as well as policing and civilian functions. The AMISOM Police component, comprising 383 officers deployed from Uganda, Nigeria, Ghana, Sierra Leone and Kenya, has the mandate to train, mentor, monitor and advise the Somali Police Force (SPF) with the aim of transforming it into an effective policing force. AMISOM military personnel are deployed across six different sectors, are composed of 6,220 Ugandan soldiers; 5,338 Burundian soldiers; 4,395 Ethiopian soldiers; 3,664 Kenyan soldiers; 1,000 Djiboutian soldiers; 850 Sierra Leone soldiers; and 75 Staff Officers in the Force Headquarters (Diego Cordano, 2015:3).

The organization Al-Shabaab has benefited from several different sources of income, ranging from extortion of local businesses in areas they control to piracy and kidnapping. In addition, the illicit trade of charcoal, sugar and illegal ivory trade have been important fund-raising activities to the organization. The group has also capitalized on purported religious credentials to impose obligatory almsgiving (zakat), and to receive donations from complicit organizations located in Saudi Arabia, Yemen, Syria, Iran, Qatar, and Eritrea(Ibid :2). The organization also recruited non-ethnic Somalis by disseminates propaganda videos in the English, Swahili, and Arabic languages.

The principles of the OAU particularly that of "non-interference 'did not guide regional relationships in the Horn. The IGAD, the previous IGADD, member states had been extensively involved in each other's internal wars for the peaceful settlement of conflicts, the maintenance of regional peace, stability and security, and the protection of human and people's rights (Sally Healy, 2009:4-5).

Without a government, Somalia was unable to exercise its membership of IGAD, or indeed any other international forum, and IGAD had difficulty confronting the problem of state breakdown. In 1993 the OAU had assigned Ethiopia the lead role in supporting peace and reconciliation in Somalia, but at that stage peace and security in Somalia was firmly on the UN agenda. The country was then in the throes of significant international interventions designed to create a secure environment for humanitarian relief operations and restore political order. But these had ended in failure in 19959 (Ibid: 8).

Since February 2008, the United States has designated al-Shabaab as a terrorist organization. In addition, Foreign Private Security Contractor companies have also been operating in the country. They include Bancroft Global Development, which has been providing counter-insurgency training to troops from Uganda and Burundi 
deployed by the AMISOM peacekeeping force with finance provided by the United States and the UN, and Dyncorp International, providing logistical sustainment operations to forces taking part in AMISOM (Diego Cordano, 2015:3).

In October 2012, Kenya intervened inside Somalia and created a buffer zone in southern Somalia. The Kenyans did not manage to inflict a strategic defeat on Al Shabaab, and failed to take the strategically important town of Kismayo. It should be noted that the Kenyan intention could have been just to protect her own interests (Stig Jarle Hasen, 2012: 4).

Ethiopia had been intervening in Somali's conflict since 1990's. Her desire is to see the re-establishment of a government in Somalia stemmed from concerns about the activities of a radical Islamist group that had surfaced in various parts of the country after the downfall of Siad Barre. Ethiopia therefore had domestic as well as regional interests in a settlement in Somalia .i.e., the issue of irredentism and assuring regional security (Sally Healy, 2009:8-9).

Operation Indian Ocean, launched by the Federal Government of Somalia (FGS) with the help of the African Union Mission in Somalia (AMISOM) as the second stage of a campaign aimed at wresting control of the remaining territories controlled by al-Shabaab. These military operations have so far regained several strategic towns in southern Somalia and have deprived al-Shabaab of valuable financial and tactical resources. (Diego Cordano, 2015:2).

\subsection{SCOPE OF THE THREAT}

The emergence of Islamism as a political force in Somalia gave the conflict a regional dimension with implications for Ethiopia and Kenya, which both have sizeable Somali communities within their borders. It also excited the interest of the US and other Western powers concerned about the threat of international terrorism (Sally Healy, 2009: 8).

Al Itihad al Islamia's vision for the reestablishment of Somalia as an Islamic state governed by Sharia law has potentially embraced all the Somali peoples of the Horn of Africa, including the Somali communities in Ethiopia and Kenya. Ethiopia therefore had domestic as well as regional interests in a settlement in Somalia (Ibid: 8-9).

Operation Indian Ocean campaign appears to remain allusive and violence within Somalia continues to prevail, with numerous terrorist attacks targeting neighbouring states involved in AMISOM operations even if FGS regain territories (Diego Cordano, 2015:2).

Al Shabaab is now expanded into Kenya, through Kenyan recruits, and Al Shabaab is clearly able to recruit in Uganda and Tanzania as well. Al Shabaab still holds some following in the region and may, as they did in the Kampala bombings of 2010, hit their enemies on their home-turf and 2015 attack on Kenyan university and before that on commercial center (Stig Jarle Hasen, 2012:5). At the same time, al-Shabaab could also try to take advantage of its links with Kenya's al-Hijrah group in order to fomenting religious clashes in neighbouring regions (Diego Cordano, 2015:6).

\subsection{THE CURRENT STATUS OF SOMALIA SECURITY}

Since May 2008 Ahmed Abdi Godane (also known as Mukhtar Abu Zubair) has held the position of Amir, before being killed by a US-led airstrike on 1 September 2014. Sheikh Ahmed Umar, also known as Abu Ubaidah, has now been nominated as the new Amir. Despite al-Shabaab's historical internal discipline, the leadership has been affected on several occasions by infighting, most prominently in 2013 when a hardline faction led by Godane seized control of the group, killing the group's co-founder Ibrahim al-Afghani (Diego Cordano, 2015:2).

Recent military operations have undoubtedly been able to improve Somalia's political, military and security situation. Since 2011 the government has achieved significant objectives; such as the recapture of Mogadishu in August 2011, held by al-Shabaab since 2009; and the seizure of the valuable port of Kismayo in September 2012, which was used by the group to raise money through taxing the town's lucrative charcoal trade. Despite these positive developments, in the latter half of 2013 al-Shabaab has proved capable of carrying out lethal attacks not only within Somalia but also in the neighbouring countries. T Ethiopia is blamed for sabotaging the TNG in 200002 and attacking the rising CIC in 2006.he territory under al-Shabaab's control has significantly reduced in 2014. (Ibid: 3-4).

But, the security situation in many parts of Southern and Central Somalia continues to be volatile4 and the capacity of the State and its institutions to protect civilians residing there remains weak, including at local level. Protracted armed conflict has had devastating consequences, including massive displacement, weakened community structures, gross human rights violations and the breakdown of law and order. Large parts of Southern and Central Somalia remain under the effective control of non-state armed groups (UNHCR, 2014:2).

Another important development has been the recent seizure of illegal arms shipments off the Somali coast, which signals the government's increasing ability to manage maritime security and undermine al-Shabaab's access to weapons and funding (Diego Cordano, 2015:4). Since the establishment of Somalia's new government in September 2012, there has been notable progress in the areas of security and the advancement of political processes 
in the country (PSCR, 2013:2).

Currently, the group still controls six towns and large portions of territory in rural areas, and continues to carry out bombings and assassinations in Somalia and in the wider region. Although al-Shabaab has been deprived of valuable financial sources and significant supplies, in most occasions it has avoided a direct confrontation with AMISON and Somali forces, leaving many towns without fighting, and opting for more asymmetrical warfare tactics. This implies its capacity to engage in direct operations has been degraded (Diego Cordano, 2015:4).

\subsection{POSSIBLE FUTURE SCENARIO}

Although Somali armed forces and AMISOM have made recognizable progress, al-Shabaab is unlikely to disappear and has demonstrated significant aptitude in terms of strategic planning and a high level of adaptability to the evolving situation. Al-Shabaab's presence in southern and central Somalia has reduced over the past months, but the group still controls key supply routes and, in rural areas, continues to exploit inter-clan tensions and local grievances to retain space in which it can operate, recruit, and obtain resources (Diego Cordano, 2015: 6).

The future of political Islamic movements in Somalia is very much tied to policies being pursued by the major powers internationally and in the region. Each of these Islamist organizations acts as a proxy of one or more regional or international powers. Unless there is a considered and deliberate policy by the international community of bringing all Somali factions in south-central Somalia to the negotiation table to hammer out a peace plan, the dominant Islamist groups will remain embroiled in Somalia's internal power struggle, more often than not through violent means (LPI, 2004:43)

The most likely scenario will be a retreat to rural areas in order to survive, and further terrorist attacks in urban areas; and increasingly, in neighbouring countries involved with AMISOM operations. This will correspond with a greater reliance on the use of suicide bombings, improvised explosive devices, hit-and-run attacks, political threats and grenade attacks. Moreover, the group appears to be increasingly proficient in their assassinations, as shown recently by the successful operations against several Somali politicians. This tactic may allow al-Shabaab to stifle political progress sought by the federal government, prevent the normalization of life in the capital, and pressurize AMISOM contributing nations with the aim of coercing a withdrawal of support for the operations (Diego Cordano, 2015:6).

What has become clear is that the international community's focus on resolving the conflict militarily and through top-down state-building has been tried too often and too long in Somalia to succeed in the near future (LPI, 2004:43).

The government of Somalia is required to make strong diplomatic cooperation with Puntland and the newly created Jubaland in the south in order to enhance security and reduce al-shebab's strength. And they have to be recognized as semi-autonomous administrations, like the recent attempts (Diego Cordano, 2015: 5).because this is one of the typical factor that undermines efforts to rebuild federal institutions, including the army.

\section{CONCLUSION}

The prolonged collapse of Somalia's central government cannot be explained as a reflection of local interests. The country's elite would profit greatly from the revival of a recognized but ineffective 'paper' state. The inability of Somalia's leaders to cobble together such a state is best explained as a product of risk aversion. Political and economic actors in collapsed states fear a change in the operating environment which is one in which they have learned to survive and profit. Such Years of anarchy followed the downfall of President Barre, and it was not until 2012, when a new internationally-backed government was installed, that the country began to enjoy a measure of stability once more.

The decades of fighting between rival warlords meant that the country was ill-equipped to deal with natural disasters such as drought, and around half a million people died in the Somali famines of 1992 and 2010-12. In 2011 AMISOM and the TFG started a concerted offensive and al-Shabab began to lose ground. Ethiopia and Kenya joined the military campaign in the second half of 2011 and by late $2012 \mathrm{Al}$-Shabab had lost administrative control over major towns in south-central Somalia whilst still maintaining influence and control over rural areas.

The strength of state institutions represents a great weakness in Somalia and is a significant obstacle in the conflict against al-Shabaab. Somalia's new leaders aim to train and equip a professional army within different period. However; the number of serving armed forces personnel is currently significantly smaller than this target figure. In addition, Somali armed forces have traditionally been an amalgamation of forces loyal to local clans and warlords. Serving personnel are poorly equipped, relying on Ethiopia and other foreign actors for basic supplies and training.

Generally, it is better to be optimist that Somalia's will maintain its sovereign statehood by their own. And they become secured and conflict free zone but it requires strong political commitment.

\section{REFERENCES}

Afyare, E., A. and Abdullahi, B. (n.d) the Somali Conflict: Root Causes, Obstacles and Peace Building Strategies, 
Institute for Security Studies, African Security Review 15.1

Amnesty International (2011) In the Line of Fire: Somalia's Children under Attack', London, United Kingdom BBC Africa (May5, 2015) Somalia: Overview

Bjorn, M. (2009) DIIS report on the Somali conflict: the Role of External Actors, Copenhagen

Center for Justice and Accountability (2014) Bringing Human Rights Abusers to Justice: Background on Somalia Center for Research and Dialogue (2004) Somalia: Path to Recovery, Building a Sustainable Peace, Mogadishu

Christian, W. (2004) Differences That Matter: The Struggle of the Marginalized in Somalia

Diego, C. (2015) the Conflict between Al-Shabab and the Federal Government of Somali

Florence, S. (2003) Clan Politics, Clan-Democracy and Conflict Regulation in Africa: The Experience of Somalia, Catholic University of Paris, Vol.2, No. 3-4

Healy, S. (2009) Peace Keeping In the Midst Of War: An Assessment of IGAD’s Contribution to Regional Security, Royal Institute of International Affairs

Healy, S. and Mark, B. (2010) Endless War: A Brief History of the Somalia Conflict, Issue 21

Joseph, K. (1993) "Strategy for the Horn of Africa," Study Project, P 1-24

Ken, M. (2003) State Collapse in Somalia: Second Thoughts, Review F African Political Economy, Vol.30, No. 97: P.405-422

Ken, M. (n.d) Mediation Efforts in Somalia, Davidson College

Life and Peace Institute (2014) Alternatives for Conflict Transformation in Somalia: A Snapshot and Analysis of Key Political Actors View and Strategies, Uppsala, Sweden

Mohammed, M. (2009) US Strategic Interest in Somalia: From Cold War Era to War on Terror, United States: ProQuest llc

Napoleon, B., A. (2010) Ethiopia's Invasion of Somalia in 2006: Motives and Lessons Learned, Department Of Political Science, Valdosta State University, Valdosta

Peace and Security Council Report (2013) Country Analysis: Somalia; Peace and Security protocol, Issue 47 Schwab, P. (1978) "Cold War in the Horn of Africa", African Affairs, Oxford University Press, Vol.77, P.6-20 Stig, H., J. (2012) the Changing Political and Security Situation in Somalia: Al-Shabab and Al-Qaeda The Atlantic Monthly Group (2015) Timeline: Somalia, 1991-2008

UNCHR (2014) UNCHR Position of Returns to Southern and Central Somalia 